\title{
nature
}

\section{Germans engage with physics}

In an attempt to reverse a declining interest in scientific careers and to remind the public that their work is interesting, German researchers have succeeded in enhancing the accessibility of physics. Others should benefit from their example.

$\mathrm{T}$ he principle that new science should be understandable to the general public was embedded in the philosophy of the Age of Enlightenment. In 1738, Voltaire published his Elément de la philosophie de Newton: mis à la portée de tout la monde, but tout la monde was in practice often restricted to that section of the European public deemed to be most in need of simple explanation: women. Francesco Algarotti's Il newtonismo per le dame (1739) was one of many pamphlets produced for 'ladies of leisure'.

Nowadays, science's 'public' has many components, including influential people who want science to be more accountable than it has been in the past, who resent being patronized by scientists and who reject the notion that understanding leads inevitably to support. Making science accessible, rather than merely understandable, is now as much a political duty as a philosophy. Germany's science community, a late starter in taking this seriously, has to reach out to a particularly distrustful public. The signs are that it is rising to the challenge in an exemplary fashion.

Two years ago, research organizations, prodded into action by a new generation of dynamic science policy leaders, started an initiative dubbed "the Public Understanding of Science and Humanities". The mistake of using that English title has since been corrected to Wissenschaft im Dialog - a more appropriate choice of words as well as language. The organizers stress that dialogue rather than acceptance is the goal, although they clearly believe that greater acceptance will follow.

Wissenschaft im Dialog, led by Joachim Treusch of Forschungszentrum Jülich, is supported practically and financially by German research organizations and foundations, as well as the federal research ministry. It was right to hire a public relations consultancy to help run and assess the programmes. The company has not only implemented the programmes designed by the scientists but has also suggested additional elements that the scientists would have been too inexperienced to think of themselves. Half-way through the first major programme of events, the "Year of Physics", the signs are that the formula is working.
The Year of Physics was first conceived by the German Physical Society (DPG), which had been worried by an alarming drop in the number of physics students and the looming gap between the number of trained physicists and employers' needs. The DPG remains the organizer, but the initiative now lies under the umbrella of Wissenschaft im Dialog, and has spawned the Year of Life Sciences (2001) and the Year of Geosciences (2002).

The events of the Year of Physics have been imaginative and wideranging. The year has been divided into five parts, each dedicated to a different physics discipline. Particle physicists are still glowing with pride at the record attendance they attracted in April to Reise zum Urknall, a series of public lectures accompanying exhibitions, one provided by CERN, taking visitors back to the Big Bang. The week-long event attracted some 15,500 visitors to the Urania, Berlin's nineteenth-century public lecture hall.

In early summer, the exhibition Gebändigtes Licht, celebrating quantum optics, saw crowds squashing into a marquee in the main square in Bonn well into the small hours on three consecutive nights. Physicists took their experiments into Bonn's department stores and banks, making active contact, they believe, with tens of thousands of 'ordinary' — and no doubt rather surprised — folk.

Other events during the year include artists-meet-science as well as hands-on 'physics is fun' experiments for children, and a season of Hollywood films with scientific themes. The project ends in Berlin in December, coinciding with celebrations of the 100th anniversary of Max Planck's quantum theory.

The Year of Physics has attracted wide media coverage. Moreover, hundreds of thousands of the public, which scientists perceive to be increasingly receptive to science, will have encountered it directly. The significant progress already made is a tribute both to researchers' dedication to the task and to the professionalism being adopted. That combination will be even more necessary, but stands to gain accordingly, when the Year of Life Sciences reaches out to a public notable for its genome phobia (see page 821).

\section{Stem cells democracy}

\section{Procrastination indicates an inappropriate lack of faith in political processes.}

$\mathrm{O}$ ne of the most surprising aspects of last week's decision by the British government to recommend that research be allowed on embryonic stem cells (see page 815 ) is not the decision itself, but the length of time it took to emerge. After all, the principle that human embryos up to 14 days old can be used in research was approved by parliament ten years ago, after lengthy public debate, when it passed the Human Fertilization and Embryology Act. A new parliamentary decision is only needed now because, in explicitly listing the types of research covered by the act, work on stem cells was not included - for the simple reason that such research was unknown at the time.

The delay is being widely interpreted as reflecting the government's nervousness about the likely public reaction to its proposal. Ever since the political fiasco over the safety of genetically modified crops, there has been an air of uncertainty hanging over how to handle sensitive decisions involving a potential clash between scientific advances - particularly those related to health and reproduction - and public sentiment. The case of BSE showed the world how this should not be done.

In contrast, the British debate on research using embryos, which has involved a lengthy dialogue between scientific, legal, religious and ethical experts, open participation by members of the public, and will culminate in a free vote in parliament, is a case study in how to do things correctly. So, although the government's caution is commendable, the appearance of hesitation is less so. Researchers have confidence in the value of the science - even if only as a necessary step towards what is being described as the 'Holy Grail' of reprogramming adult stem cells. Politicians should have equal confidence in the robustness of the democratic process. 